\title{
Swiss go to polls again on nuclear issue
}

Local democracy continues to block nuclear power in Switzerland. Geoff Milnes explains the latest debate over waste disposal

THE further development of nuclear power in Switzerland is grinding to a halt because of the refusal of local authorities to allow test borings in the search for suitable repository sites for radioactive waste. This is for many people an unwelcome effect of direct democracy and local autonomy-two characteristics of political life in Switzerland of which the country is justly proud. Local resistance to test borings has lead to a polarisation which has spread to the whole question of the role of nuclear energy. This became clear in the campaign leading up to the plebiscite on 18 February, in which $49 \%$ of the voters were in favour of a ruling which would probably have brought nuclear development to a complete halt, by demanding popular control of the siting of nuclear facilities by the local population surrounding the proposed sites.

Moreover the situation will remain critical if a revision of the law which recently passed through parliament is turned down in the next referendum, in May.

The present law governing nuclear power plants was put into force in 1959 with the idea of encouraging the peaceful use of atomic energy by the electricity companies, which are mixed

\section{What the geologists say about where to bury the waste}

A RECENT book* assesses the alternatives for disposing of the radioactive waste from Switzerland's nuclear power plants, assuming that by the year 2000 a final capacity of $5 \times 1,000 \mathrm{MWe}$ will be reached. From the geological point of view, radioactive wastes can be put into two categories, according to the length of time that isolation from the biosphere is required.

The first category, low-active waste (NAA), consists of contaminated materials from the normal running of power stations (filter residues, wornout parts, tools, clothing, etc) and the radioactive debris produced on demolition after the projected 40-year running life. This material contains only short-lived radio-nuclides in small amounts and needs isolation for a few hundred years. The total volume will probably be about $85,000 \mathrm{~m}^{3}$.

The second category is the highlevel $\alpha$-bearing waste (HAA) which originates from the reprocessing of private and cantonal bodies run on a private enterprise basis. Licensing was placed in the hands of the Bundesrat (the seven-man cabinet) with no direct democratic or parliamentary control. There was little controversy until mid-1974 when newspapers reported surreptitious drilling by a little-known organisation, NAGRA, looking for repository sites for radioactive waste in a number of localities-without the permission of the local authorities.

This action, together with the obvious and painful dependence of Switzerland on foreign energy supplies emphasised by the oil crisis of $1973 / 74$, a series of frightening projections of future energy requirements, and plans for building 10-15 nuclear power stations which appeared at about the same time, resulted in a tremendous upsurge of public interest and concern.

NAGRA (Nationale Genossenschaft für die Lagerung Radioaktiver Abfälle) is a cooperative organisation founded in 1972 by the "waste producers"- the companies operating or planning to operate nuclear power stations (six companies in all) and the confederal government (responsible for radioactive wastes derived from hospitals, industry and research) - each with one delegate on the administrative board.

the spent fuel. Switzerland depends on foreign plants for fuel reprocessing, but must assume that high-level wastes from these plants will be returned to the country for disposal after an initial storage period. With present reprocessing procedures, which seem unlikely to change drastically in the near future, HAA will contain quantities of plutonium and $\alpha$ emitters with long half lives which require containment times of at least 100,000 years. However, the total amount of HAA wil probably be small (about $400 \mathrm{~m}^{3}$ ).

However, several factors make Switzerland far from ideal for the location of radioactive waste repositories, particularly for HAA. These include the complicated geological structure, the humid climate and the complex hydrogeological conditions, the possibility of renewed extensive glaciation and the continuing tectonoseismic activity.

Near-surface mined cavities for low level waste: NAGRA has been contracting research in this direction for a number of years. Research has concentrated on anhydrite as the host rock for NAA repositories. Pure
This board contracts research in various directions, financed in proportion by the companies and the government-in waste treatment and conditioning, in the development of repository concepts, and in geological studies. The latter has turned out to be the politically critical area.

Switzerland is one of the few countries without a geological survey-and there is no tradition of free flow of geological data, since most studies are carried out by private companies in competition with each other. The NAGRA research was thus contracted out to a private geological bureau. Also, NAGRA became a member of a further institution, KUS (Konsortium für Untertagsspeicher), set up to coordinate all work on underground storage, including the storage of oil and natural gas. In 1974, none of these bodies were in the public eye and the complicated inter-relationships made it difficult for the individual landowners to grasp for what and for whom the geological investigations, including test drilling, were to be carried out, when permission was being sought for land access.

Whether this confusion was a result of a basically nuclear legal situation (NAGRA's view) or whether it was the result of a deliberate policy of secrecy and stealth (the anti-nuclear front's opinion) is hard to judge.

anhydrite is suitable for cavern construction and has good sorption characteristics and thermal conductivity. It is also generally impermeable to ground-water near the surface, because of a "self-healing" effect caused by its rapid conversion to gypsum (with a volume increase of $60 \%$ ) when water percolates along cracks and fractures. Anhydrite-bearing formations are widespread in Switzerland, though occurrences of pure anhydrite of sufficient size have not yet been found. The anhydrite occurrences known are all very impure and heterogeneous, often chaotically mixed with other rocks or found along fracture zones with rapidly varying thickness. Investigation on other potential host formations (shale, granite) have not yet been carried out. So, although a reasonable solution can be expected in this direction, the research and development programme is still in its infancy.

Deep borehole repositories for high level waste: The book proposes a fanned array of deep boreholes, penetrating a $350 \mathrm{~m}$ thick host formation at a depth of $1-2 \frac{1}{2} \mathrm{~km}$. Various potential host rocks-rock salt, anhy- 
Nevertheless, when the news broke that test borings in connection with the search for suitable underground repositories for nuclear wastes were in progress in several places without official knowledge or consent of the Gemeinde in question, a great cry went up.

Since 1974, no further test borings have been possible and the resolution of this stalemate has become a key issue in the nuclear power controversy. The core of the legal problem seems to be that the Bundesrat, under the law of 1959 which is still in force, is only responsible for site licences and permits once a site has been selected. NAGRA has always emphasised, however, that the test borings were exploratory, preceding site selection.

The Bundesrat has thus decided that they are governed by the normal laws applied to mining, search for oil, etc, for which the Canton is responsible, after consultation with the Gemeinde concerned. NAGRA lawyers maintain that the preliminary investigations must be considered as an integral part of the nuclear facilities themselves, coming under confederal law, and so the NAGRA put in applications for permits to carry out the borings to the Confederate Energy Office in 1976. These are still pending.

This is not the only legal bone of contention. The other important one concerns the licensing of the power stations themselves. The anti-nuclear

drite, shale, marl, gneiss, granite-are possible, but few are thought to occur at convenient depths in sufficient thickness (probably only gneiss and granite). Potential sites are more likely to be found outside the mountain areas, i.e. under the Swiss Plain (Molasse basin). In the Alps, the deep structure is very complicated and difficult to predict and the danger of a new Ice Age and rapid glacial erosion in the next 100,000 years cannot be ignored.

A repository at $1-2 \frac{1}{2} \mathrm{~km}$ depth in a suitable area is unlikely to be affected by "external" effects-human influences, meteorite impact, volcanic eruption, glacial erosion-during that period. The relatively high seismic risk in some areas is a more serious problem because the fracturing associated with earthquake activity could affect the underground water circulation, which is critical for the integrity of any repository. Information about the numerous hot spring and mineral water occurrences indicate high permeabilities and rapid groundwater circulation in some deep formations. It will be necessary to gather detailed information on the flow types, velocities and chemistry of the movement, supported by eminent lawyers, maintains that the proof of safety of nuclear power stations, a necessary condition for the granting of construction licences, includes also the safe disposal of the radioactive wastes, and that this cannot be produced prior to repository site selection, i.e. before test borings have been made.

This is just one of a series of irregularities which lead them to the conclusion that the nuclear plants now in operation (three, with a total capacity of $1,000 \mathrm{MWe}$ ) and the two $1000 \mathrm{MWe}$ units at present under construction were illegally licensed. In the general atmosphere of public discontent, as illustrated by last month's vote, the Bundesrat has considered it politically inopportune to license further works under the old law (the Kaiseraugst works, whose site was occupied by demonstrators for 6 weeks in spring 1975, is one whose licence is still pending). Instead, it set a commission to work to revise it.

The new law, which passed through parliament in a number of turbulent sessions in spring 1978, contained several improvements and clarifications most of which intended to place the nuclear industry under stricter and more democratic control, with regulations which, in contrast to the old law, should rather discourage nuclear power growth unless absolutely necessary.

For the "borehole stalemate", however, the new law brings some relief- test borings for power stations or waste repositories can be forced through by the confederal authorities by expropriation of land, if necessary. But the situation is still tense.

A section of the anti-nuclear movement decided that the stalemate suited their purposes well and have forced a referendum against the revision of the 1959 law (voting takes place on 20 May). In this, they have laid themselves open to accusations of illogical obstructionism by the nuclear power supporters -it is pointed out that one of the opponents main arguments against nuclear power is that the problem of radioactive waste disposal is not solved, and yet their activities are directed towards preventing the very investigations necessary to reach a solution.

The anti-nuclear group is intent on preventing the waste disposal problem -which must be solved whether more nuclear plants are put into operation or not-from being approached in the scientific way it deserves. In so doing, it risks alienating that part of the antinuclear movement which takes a broader view of the whole energy problem and which is interested only in nuclear power being kept within carefully and democratically controlled limits. Be that as it may, the Swiss voters will be asked to decide another nuclear issue in May and an important public debate continues.

Geoff Milnes is at the Geology Institute, ETH, Zurich.

groundwater and on the sorption properties of the surrounding rocks in the vicinity of the repositories. These are local parameters, not predictable from surface studies-their investigation requires exploratory deep drilling and long-term, on-site experiments. This is a costly and timeconsuming business and is by no means sure of success. Ten to 15 years of directed research will be required before the feasibility of this concept can be settled.

The alternative to the two concepts summarised above is cooperation in an international programme such as the "seabed" programme. Whether the two concepts can be realised also depends also on social and political aspects. The situation is aggravated by the lack of an established geological survey and because the research, being carried out mainly with private financial support in a piecemeal fashion, is not published and not made available to the general public. It seems clear, however, that even with the most favourable political developments, the scientific and technical problems are such that a practical solution and definitive site selection can hardly be expected

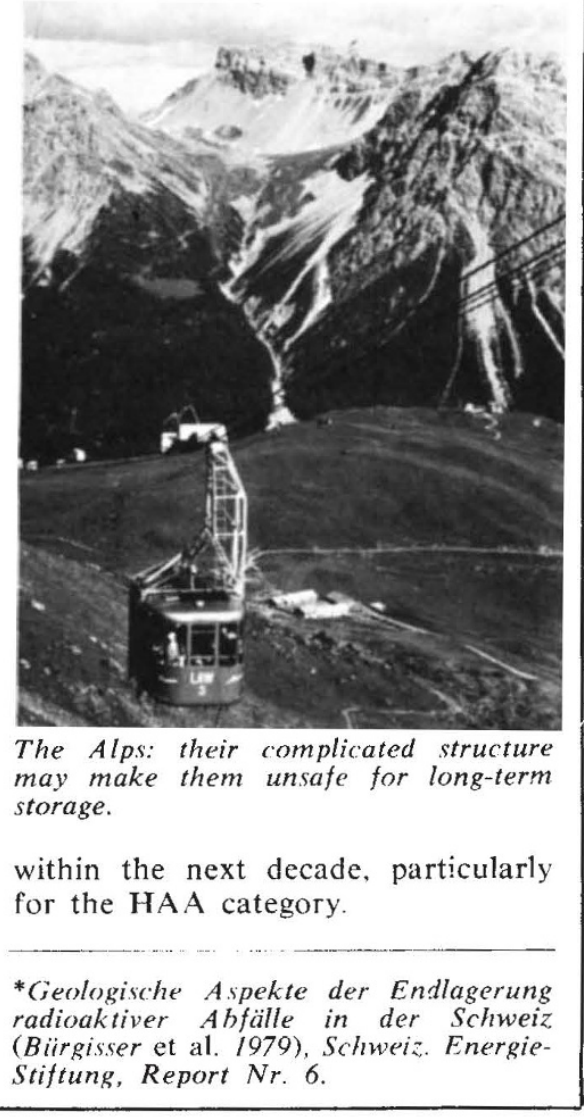

